\title{
Vanished in gaps, vanquished in rifts: the social ecology of urban spatial change in a working class residential area, Peykan-Shahr, Tehran, Iran
}

\author{
Ilia Farahani ${ }^{1}$ \\ Lund University, Sweden
}

\section{Introduction}

The intensifying planetary ecological crisis tied it to industrial production has given rise to a development of ecological Marxist research. Marxist ecology distinguishes itself from other ecological paradigms by concentrating on the social relations of the capitalist mode of production, and links the current ecological crisis to the inherent, inevitable and endless hunger of this mode of production to accumulate capital (see Foster et al. 2010). Similarly, an acceleration of urbanization and the emergence of megacities, especially in the global South, have provided a fruitful intellectual context for eco-Marxist inquiry (see Davis 2006; Williams 2010). The emergence of the theory of socio-ecological 'metabolic rift' is deeply rooted in this intellectual turn. Despite these emerging inquiries, there is little eco-Marxist research into the social ecology of socio-geographical changes in urban spaces, and particularly the theory of metabolic rift. This study aims to understand the forms and processes of socio-ecological change following socio-geographical displacement of workers in an industrial working class residential area in Tehran, Iran. It aspires to be sensitive in identifying, extending, and modifying theoretical foundations in order to analyze the consequences of displacement.

Peykan-Shahr is located in Tehran's western suburbs. It is a classic example of Iranian autoworkers' accommodation. Built in 1969 to accommodate workers in Iran's first and the largest auto-industry, the 'Iran Khodro Industrial Group', it is a fenced housing development of roughly 18 ha. A change in ownership was kicked off in 2002 by the selling-off of residential units and land into private ownership, with the first purchase options going to the tenants. This change in ownership stimulated a price hike of the property and residential units but has, as of yet, not induced any short-term changes in the built environment or redevelopment of the township. The case provides evidence of housing transitions that could be experienced elsewhere and affecting Iran's working class.

\section{Methodology}

My empirical study is divided into two sections: case study and participant observation. The research can be seen, following Creswell (2007), as a "single instrumental" case study. I have focused on the dislocation of workers from their houses in Peykan-Shahr, examining how the theoretical strands are related to my empirical findings (Creswell 2007: 74). This is explanatory research (Yin 2009) as it tries to question and explain how gentrification plays a key role in increasing capital's pressure on both labor and nature in order to yield rent. Likewise, the research is concerned with how those possible findings are related to the theoretical frameworks I adopt.

I completed a one-month long participant observation in addition to scrutinizing official resources and Fariborz Raisdana's economic analyses. I used statistical data prepared by UNDP, the CIA World Factbook, the Central Bank of Iran, Statistical Center of Iran, Tehran Municipality, and Tehran Metro. Participant observation has a particular importance in researching the Iranian economy since other data can be unreliable or unavailable. Official data is politicized and even the two main economic institutes-Iran's Statistical Center and Central Bank of Iran-do not always concur (Hessamian et al. 2008; Nomani and Behdad 2006; Raisdana 2001, 2002).

I applied qualitative and quantitative methods during fieldwork. My aim was to prepare a history of the location, identify the main driving forces and agents of the spatial change, and collect data on property. I

\footnotetext{
${ }^{1}$ Mr. Ilia Farahani, Master of Science in 'Human Ecology; Culture, Power and Sustainability', Human Ecology Division, Human Geography Department, Lund University, Sweden. E-mail: ilia.farahani@gmail.com. I would like to express my gratitude and intellectual indebtedness to Prof. Eric Clark, Human Geography Department, Lund University and Turaj S. Faran, Lund University Center for Sustainability Studies (LUCSUS) for their generous intellectual as well as technical support without which the present research would not have been possible. I am also grateful to Jacquelyn Schneller for her help while writing this article. Thank you to Profs. John Bellamy Foster and Fariborz Raisdana for their support. My special gratitude goes to my anonymous informants for all the kind helps they gave. I would also like to thank the editors Simon Batterbury and Casey Walsh, and four anonymous reviewers.
} 
conducted purposeful discussions with stakeholders, by asking specific questions without formally interviewing them. Respondents included two workers, five labor activists, three previous and three present inhabitants, ten local estate agents, and Fariborz Raisdana, an independent economist.

I asked about the background of the area, rents, prices, ownership, social problems and tensions, the working day, overtime, wages, number of workers of the firm, number of dwellers of the township, changes after sell-offs, changes in healthcare and insurance, security, maintenance, sewage management, guards, shops, education, schools, transportation, trade union membership, urban management and the role of the municipality, the area and other features of the residential units and building blocks, products of the firm and its periods of boom or recession, contracts, job security and condition, tenant formation, position of the township in the neighboring area, share of banks in the firm, etc.

The main difficulties encountered were a prohibition of photography in Tehran, and limited access to data. Due to security reasons, I accepted most of my interviewees' preference to hide their identities. This helped me to protect "the rights of individuals, communities and environment involved in, or affected by" my research. Secondly, "ethical behavior helps assure a favorable climate for the continued conduct of scientific inquiry" (Hay 2008: 39). But regrettably I could not let some of my interviewees know my purpose and sometimes, even had to hide my own identity. For example, in collecting data from estate agents, in five cases I played the role of a buyer-whether a customer (for tenancy or ownership) or a redeveloper-and in five cases the role of a seller. Estate agents are among the most reliable sources for collecting data about prices, rents, redevelopment, speculation, etc. They have access to an online network database that connects them to their fellow agents. Their emergence is related to the potential of a region to redevelop and most of them will actively participate in redevelopment as investors.

My initial approach was to turn to existing political economic analyses of construction and housing in Iran. This was helpful in identifying the main driving forces involved in local housing production. The analytical difficulty to address was whether gentrification could take place in Peykan-Shahr.

\section{Theoretical frameworks}

Although the changes in the built environment (including changes in ownership in low-income working class residential neighborhoods) have been studied by Iranian social scientists, they have yet to be studied from a socio-ecological perspective or with a focus on their socio-ecological consequences. Among Iranian economists, Fariborz Raisdana has a privileged position. This is because firstly, in his analysis of Iranian political economy, he has paid particular attention to construction and urban housing (2002). Secondly, his research on housing (2001) systematically addresses and identifies politico-economic drivers of change, which distinguish him from other Iranian economists. Thirdly, considering a lack and/or unreliability of official data, his empirical and analytical studies, including his statistical and econometrical analyses provide valuable bases for the present study.

Raisdana argues against the possibility of gentrification in Iran, as do several geographers and gentrification theorists focusing on non-western countries. He challenges some of the classic readings of gentrification theory, which include the replacement of low income working class with young middle-class families with higher level of income; theories that consider finance capital as the main driving force (especially in the global South); and certain ideas about the commodification of housing (e.g. Smith 1986; 1996). He argues that Iranian gentrification is a problematic concept for two reasons: first, because we cannot find any interest-whether cultural or social-among the middle-class in usurping the working class in their neighborhoods; and second, because most public housing cannot enter the free market (Raisdana 2001). Following from this sociological and economic critique, he suggests a need for more equitable state regulation in the housing market (Ibid.).

\section{Gentrification and rent theory}

The primary aspects of a gentrification process were observed in the 1960s in a few advanced capitalist metropolises (Lees, Slater and Wyly 2008; Smith 1996). The term itself was coined by Ruth Glass in 1964 to elucidate a class dislocation induced by modern urban housing policies in London (Glass 1964). The initial movement was a displacement of the low-income working class in the inner city by upper and middle class households from suburban or other parts of the city (Smith 1986). The trend was observed more widely in large and older cities in advanced capitalist countries after 1970 (Lees, Slater and Wyly 2008; Smith 1996). The more recent expansion of the phenomenon to the global South is largely seen as an expansion promoted and regulated by globalized finance capital (Atkinson and Bridges 2005; Lees, Slater and Wyly 2008; Smith 1996).

Most of the scholarly work on gentrification is based on an economic (rather than social) understanding of spatial transformation (see Atkinson and Bridges 2005; Clark 2005; Lees, Slater and Wyly 2008; Slater 2006; Smith 1996). Besides, "more attention was paid to the effect of the gentrification of the 
working class than to the characteristics of the new middle class that was moving in" (Slater, Curran and Lees 2004: 1144).

Neil Smith (1996: 39) tried to broaden the classic definition of gentrification by saying "Gentrification is no longer about a narrow and quixotic oddity in the housing market but has become the leading residential edge of a much larger endeavor: the class remake of the central urban landscape". But his work did not embrace other forms of the phenomenon including gentrification in suburban and rural spaces. A recent broad study, by contrast, says, "Gentrification of an area is characterized by both a marked upward shift in occupancy in terms of class and socio-economic position and associated reinvestment in the built environment" (Hedin et al. 2012: 447-448). Similarly, Clark (2010: 25) criticizes narrowness in definition (the rehabilitation of inner city's residential areas) and broadens it to any process that involves "a change in the population of land-users" with "a higher socio-economic status . . . together with a reinvestment in fixed capital". This is helpful in analyzing patterns of socio-spatial change (dislocation of the workers of the neighborhood), changes in the ownership and tenure, production of space, social characteristics of newcomers, and the future state of the neighborhood of Peykan-Shahr. It is also helpful in criticizing Raisdana's position on the lack of gentrification possibilities in Tehran. However, a question still remains: why do redevelopers find some neighborhoods more profitable than others (Smith 1996: 57)?

The level of rent indicates "a quantitative measure of the actual forces" involved in urban spatial change (Smith 1996: 81). An appropriate theory of rent is important, therefore, as it clarifies not just capitallabor relations but also the relationships between capital and land (Murray 1977: 100). These socio-economic relations are responsible for stimulating urban (and rural) land use and spatial change. More specifically, they are responsible in the present study for Iran Khodro's decision to sell-off the township, and the resultant price hike as dwellings came onto the market. The common application of rent theory in gentrification literature is more relying on Ricardo, the present paper, in contrast, is relying on Marx. Therefore, a brief review of the difference between Marx and Ricardo’s conceptualizations of land rent seems required. Such a review could illuminate the bases of my critique of Ricardian conceptualizations of land rent in urban space and gentrification theory, and neglecting absolute rent, for instance by, Harvey, Smith and Clark (see below).

For Marx (as for Ricardo) the price of the land "represents a deduction from value produced elsewhere" and not directly as a factor of production as it is for 'vulgar' economists (Murray 1977: 102). But Marx confronts Ricardo when explaining the difference between rent yielded from two parcels of agricultural land with different level of fertility, but with equal level of capital investment. Ricardo's response to this question is that "agricultural prices were determined by the labour time embodied in the commodities produced on the least fertile cultivated land" (p102). According to him, rent could only emerge for land with a higher level of fertility. Or, in other words, the least fertile land had no rent (Murray 1977: 103).

Assuming wages to be constant, Ricardo theorized capitalist distribution and a falling rate of profit (when rent increases). Marx, however, argued that Ricardo's "failure to distinguish constant and variable capital" prevents him from realizing the main drivers of the falling rate of profit (Murray 1977: 103). Marx makes two points. First, he says, "rent may rise at the expense of [exchange-value of] wages... even where real wages are held constant" (p103). Thus, a rise in rent might result in an equal or even greater profit. Second, "rent can rise without affecting either profits or wages" (p103). This time the rise in rent is based on "the relative differences between plots rather than a fall in the absolute productivity on the worst land" (p103). Rather than a falling rate of profit elsewhere, this increase in rent comes from "an increase in the difference between the value of production in the individual plots and the value on the marginal plot which governed the commensuration of agricultural labour to labour in the rest of the economy" (Murray 1977: 103). Marx's point here is based on his understanding of value as "embodying socially necessary labour time established by the commensuration of labour between branches" not "individual labour time embodied in the isolated commodity" (Ibid.). Furthermore, he saw soil fertility as a social matter, rooted in historical socio-economic relations and not as a pure natural attribute, as Ricardo saw it: a view that led Ricardo to "build a general theory on a special case" (Murray 1977:104).

These points form the theoretical basis of Marx's two types of differential rent. The extensive differential rent is differential rent I (DRI), which results from investing equal quantities of capital to different plots, and the intensive differential rent is differential rent II (DRII) that is yielded through "the application of equal amounts of capital successively to the same plot" (Clark 2004: 150; Murray 1977: 104). Thus, while DRI is based on "relative advantages in fertility or location", DRII is based on "differences in capital investment" (Clark 2004: 150). Investigating "alternative movements" of the two types of differential rent, Marx wants "to break the tight relationship Ricardo had established between increases in output, declining fertility, and rising rent" (Murray 1977: 104). He criticizes Ricardo's argument that the relationship between rising rent and falling profit is exceptional, since there is "no necessary relation between changes in rent and changes in profit" (Ibid., p 106).

Marx's next step was to identify the distinction between values and prices of production, and the process of transformation of value into price. He develops his concept of absolute rent to explain the difference between rates of profit in sectors with different organic composition of capital. This explains 
capital's tendency to flow between different sectors. In other words, competition allows capital to flow and then to equalize the rate of profit and guarantee the next run of production (Murray 1977: 107).

Marx argues that a low organic composition of capital (i.e. the ratio of constant to variable capital) in agriculture should secure a higher rate of profit than the social average. But "landed property presents a barrier to prospective capital, by demanding a rent even on marginal land" (Murray 1977: 107). This social tension between capital and landed property (or landownership) prevents agriculture from interfering with "the general process of profit equalization" (Ibid.). Therefore, prices of agricultural products "continue to reflect their value rather than post-equalization process of production" (Ibid.). The rent the landlord tries to extract is the excess profit rooted in the difference between price of production and value (Ibid.) ${ }^{2}$.

Marx's analysis of the social tension between landowner-capitalist-laborer is also relevant in explaining capital's tendency to intensify exploitation of labor and nature. Because natural conditions of production (as use-values) are "scarce and monopolizable"; and also, no human labor is used in their production (so, they are freely appropriated by landowners), then, their market prices involve the transfer of value from industrialists to landowners (Burkett 1999: 91). Therefore, the extraction of rent by landowners plays a key role in the separation of labor from nature-such separation referred to below as 'metabolic rift'and capital's intensified exploitation of both (Ibid., p 94; Burkett and Foster 2006: 141).

As for rent in urban space, David Harvey coined the concept of class-monopoly rent to explain the actual "payment made to the owners of land" (Harvey 1985: 90). He insists that the extraction of classmonopoly rent could only be possible if the landowners could collect and act as a class. Therefore, the extraction of this type of rent is attributed to a class conflict between landlords and low-income tenants (Harvey 1985: 67). To explain capital's flow onto land in the form of built environments, he relies on the interplay between two types of differential rent (DR II and I, see above) through which they constitute conditions for and impose limits upon one another (Harvey 2006: 354-356).

Smith names three aspects of land and "the improvements built on it" that form its position in the capitalist market. Firstly, property rights allow the landowner to have a "near-monopoly" that could help them to manipulate the market. Secondly, land and its improvements are spatially "fixed" while their value is not. Thus, the price of the building also reflects land rent. Thirdly, "land is permanent" while the improvements, despite having "a very long turnover period in physical as well as value terms", are not (Smith 1996: 58-59).

The physical turnover of the built environment, economically speaking, indicates a specific form of devalorization of capital invested on it. Therefore, "a theory of gentrification will need to explain the historical process of capital devalorization in the inner city and the precise way in which this devalorization produces the possibility of profitable reinvestment" (Smith 1996: 61). Smith saw property value as a sum of building value and land value. To understand the relationship between these two values, he disaggregates them into four categories of "house value, sale price, capitalized ground rent and potential ground rent" as a means of measuring the value of the property (Ibid.). House value is measured by the socially necessary labor time needed for its production and maintenance. The value will be translated into price, when the commodity (the house) enters the competitive market. The sale price consists of the sum of house value and capitalized ground rent. Capitalized (or more precisely, actual) ground rent reflects "the value of use of the site for a given period (let us assume annual), given the current intensity and type of use". Potential ground rent reflects "the annual land rent of the site given the 'highest and best use"' (Clark 1995: 1492). ${ }^{3}$

An increase in land rent, during the first cycle of use, supports a rise in sale price. During the first cycle, the built environment will gradually lose value as it ages, with impending "regular, minor repair" or potentially more major works (Smith 1996: 64). "Devalorization will induce a price decrease relative to new housing but the extent of this overall decrease will depend on how much the ground rent has also changed in the meantime" (Ibid.). Most owners can afford the expense of major repairs and can therefore maintain the value of a neighborhood, so houses are unlikely to be demolished.

Gentrification usually occurs with "revaluation" of capital in working class or low-income strata neighborhoods whose residents cannot afford the rise in costs of maintenance, rent and prices. The spatial change starts with abandonment and disinvestment of the area by the landowner when the house rent cannot cover the maintenance costs (Smith 1996: 67). Dwellings deteriorate and the neighborhood gradually worsens until reinvestment and redevelopment becomes profitable. Hence, the tendency for gentrification of a neighborhood is related to "the complexity of capital mobility in and out of the built environment" (Smith

\footnotetext{
${ }^{2}$ Stated differently, "Such a capital produces more surplus-value given the same exploitation of labour, and therefore more profit, than an equally large aliquot part of the average social capital, because it applies more living labour. The value of its product thus stands above its price of production, because this price of production is equal to the replacement of the capital plus the average profit, and the average profit is less than the profit produced in this commodity. The surplus-value produced by the average social capital is less than the surplus-value produced by a capital of this low composition" (Marx 1991, III: 893).

${ }^{3}$ For a broader account on different categories of land rent in rent gap theory, see Clark 1995.
} 
1996: 51) and the extent (and thereby the force) of the rent gaps, or of the value gaps, or both. ${ }^{4}$ As Smith says, a widened rent gap allows the sale price of the renovated/redeveloped area to be more desirable than purchasing and renovation costs, mortgage interest and construction loans combined. A widened value gap puts a "greater economic pressure on the property owner to realize the potential capital gain connected with selling out to individual owner occupiers and to place that capital in higher-yielding investments" (Clark 1992: 18). Thus, it induces a price hike in land and building value, as a result of a change in tenure.

For Smith (as for Ricardo) the flow of capital from industry to the construction sector is related to the general crisis of capitalism, i.e. falling rate of profit in competing sectors like manufacturing. A "systemic disinvestment" in "the previously developed" and now underdeveloped inner city, therefore, induces the rent gap (Smith 1996: 86). The gap forms a basis for a "locational switch" through a considerable reinvestment of capital in the built environment.

\section{Theory of metabolic rift}

The idea of socio-ecological metabolic rift finds its roots in Marx's historical materialism, on one hand, and his study of Hermann and Liebig's physiology and chemistry of soil, on the other. The idea is that the transformation of agriculture to industry causes;

...a rift in the metabolic interaction between man and the earth or in the social metabolism prescribed by the natural laws of life, through the removal from the soil of its constituent elements, requiring its systematic restoration (Foster 1999: 380).

It indicates that capital's free appropriation of natural resources as a primary condition of production leads it to exploit labor and nature simultaneously and to cause a rift in their metabolic relationship (Foster 2000; Foster et al. 2010). This might seem incommensurable with a study of changes in urban space, but the theory addresses a rift resulting from industrialization and capital accumulation (Foster 1999; Foster 2000; Foster et al. 2010). I argue that by applying modifications one can extend this theory to urban spatial change and analyze the socio-ecological consequences of dislocation in Peykan-Shahr. It sheds some light on the development of Peykan-Shahr from a marginal wasteland to a part of the metropolis.

Marx's analysis of this metabolic rift is based on his labor theory of value and the historical specificity of capitalist production and in that sense, is inherently related to capitalism's basic contradiction between usevalue and exchange-value. It also forms part of a particular understanding of sustainability flowing from his analysis (Foster 2000; Foster et al. 2010). The theory of metabolic rift illuminates social and ecological impacts of urbanization and transformation of rural to urban. Furthermore, by identifying labor as a natural (and social) condition of production, it elucidates that changes in the conditions of reproduction of labor-in this instance, housing-in Peykan-Shahr has both social and ecological consequences.

Capitalist production is dependent on "environmental input of labor power and non-human matterenergy" (Burkett and Foster 2006: 140). Development of industry and of industrial agriculture is based on "the systematic and intensive robbing of the soil" and exploitation of labor. Industrialization, with consequent urbanization, has intensive ecological impacts as it "prevents the return of the soil of its constituent elements" (Ibid.). Furthermore, capitalist industrialization depends on "the social separation of producers from the land" by displacing rural populations to industrial areas, and from "other necessary conditions of production" within industrial urban life (Ibid., p 142).

The labor process is "the main metabolic relation between humans and nature" (Ibid., p 118). The term labor-power is used to explore the mental, physical, energetic, and material character of labor. Labor power, like any other commodity in capitalist production, has use and exchange value. "The use of labour-power is ... labour itself', and 'the purchaser of labour-power consumes it by setting the seller of it to work"' (Ibid.). Its value, on the other hand, can be measured by "the value of the commodities" consumed by workers in the process of labor reproduction.

This consumption has physical and intellectual dimensions. Physical aspects include "workers' 'natural needs, such as food, clothing, fuel and housing"' (Ibid.). Any obstacles in meeting these basic needs (in the present study, housing) would induce "matter-energy dissipation" and a rift in the workers' energeticmetabolic reproduction. As for intellectual aspects, capital restricts workers' access to intellectual resources, such as schools, libraries, universities, etc., by reducing workers' free time to develop and reproduce their intellectual being (Burkett 1999).

\footnotetext{
4 "The rent gap is the disparity between the potential ground rent level and the actual ground rent capitalized under the present land use" (Smith 1996: 67). The term 'value gap' refers to a disparity between property value under owneroccupied tenure and as rental property (Clark 1992).
} 
The value of labor is dependent on a worker's ability to reproduce him/herself and his/her generation in the workforce;

If the owner of labour-power works today, tomorrow he must again be able to repeat the same process in the same condition as regards health and strength. His means of subsistence must therefore be sufficient to maintain him in his normal state as a working individual (Marx 1990, I: 274-275; quoted in Burkett and Foster 2006: 121).

Therefore, by making this energetic-metabolic rift, capital de-qualifies workers' "natural needs both in production and consumption" (Burkett 1999: 168).

The source of profit in a capitalist system is surplus value extracted by capital from both surplus-or unpaid-labor and its natural basis. It relies on "capital's tendency to extend work-time"..."to obtain the greatest possible quantity of living labour time"' (Ibid., 134; Marx 1990). Marx (1990) defines two forms of relative and absolute surplus value. Extraction of relative surplus value occurs with technological change and subsequence gain in productivity. Extraction of absolute surplus value is based on direct increase in the working-day. Extraction of absolute surplus value has obviously physical limits; "The worker cannot be treated like a steam engine that will just keep running as long as adequate coal is shoveled in" (Burkett and Foster 2006: 121). The imperatives of private property and competitive monetary accumulation that force capital to extend working-day lead to an exploitation of the social and natural "elasticity of labor power's requirements" (Burkett 1999: 134). Thus, if capital's exploitation of labor through extended work-time exceeds the natural limits of labor reproduction, it would cause a rift in the labor metabolic interaction with nature. As we will see below, the extraction of absolute surplus value by Iran Khodro (extending workingdays up to 18 hours a day) plays a key role in maximization of the profit by the firm. The price hike of the residential units in Peykan-Shahr after the sell-offs and increasing living expenses, which led many workers to take of a second job, shows how the changes affects the condition of labor reproduction.

\section{Peykan-Shahr}

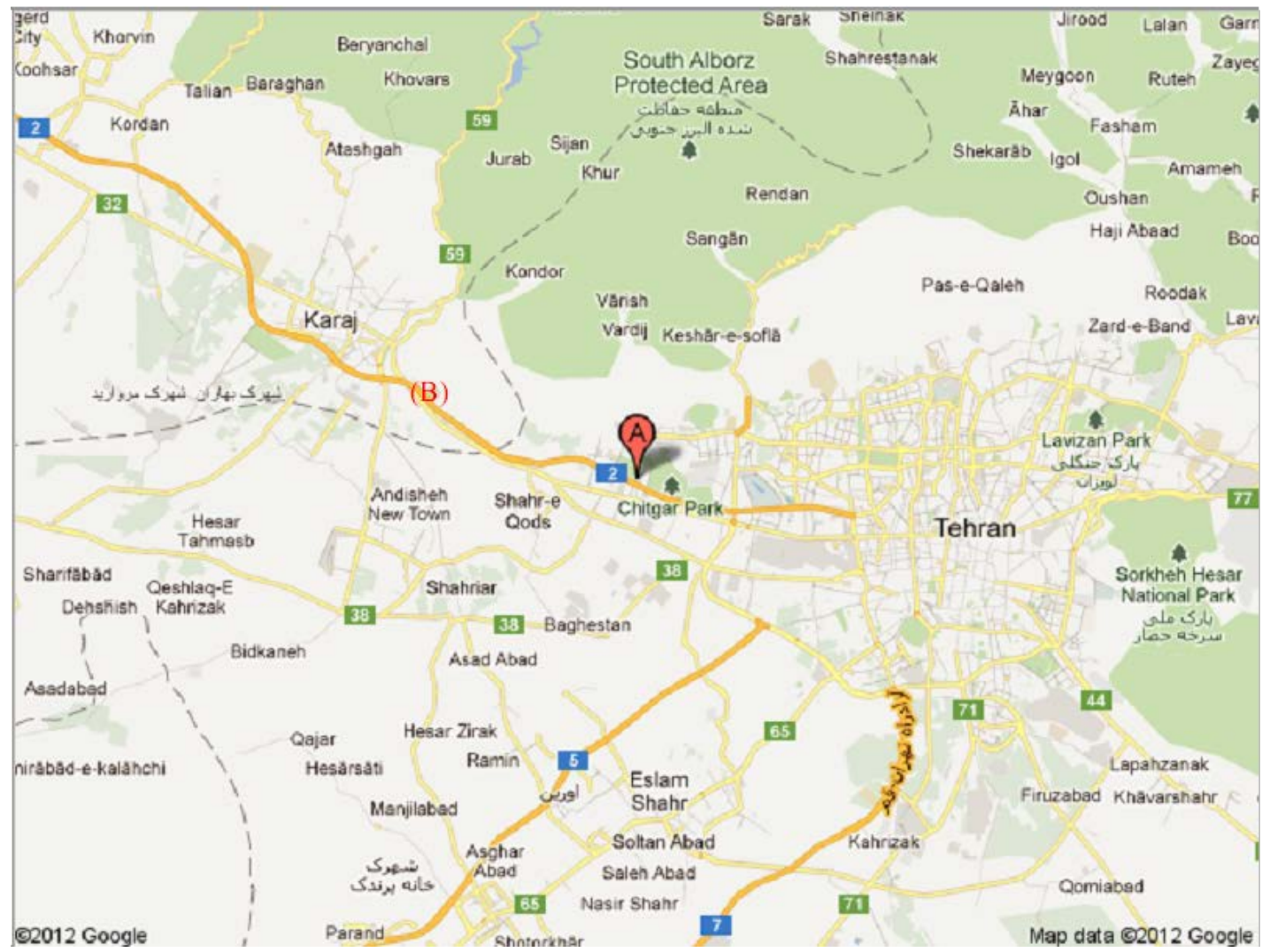

Figure 1: Overview I (A) Peykan-Shahr (B) Tehran-Karaj Freeway Source: Google Earth. 
By 1969, during its construction phase, the newly established Iran National Company (later Iran Khodro Industrial Group) started to construct Peykan-Shahr-a small township to accommodate its workers (Iran Khodro Website). Both the firm and the township were located 24 kilometers from the center of Tehran, the capital of Iran. The 42 kilometers-long Tehran-Karaj Freeway, (constructed in 1966) that connects Tehran to Karaj, separates the firm from the township (see Figure 1). Peykan-Shahr neighborhood is located in the northern side while the firm's main site is located in the southern sides of the freeway (see Figure 2).

Iran National was established in 1962. The primary amount of capital invested in Iran National, including the vast and almost free marginal wastelands of Tehran-Karaj Freeway (it had been appropriated as consecrated land during land reforms of the 1960s), credits and machinery, was around US\$ 6 million (Iran Khodro Website; Khayamy Blog; Hessamian et al. 2008; Informants 2, 7). Later, Iran Khodro Industrial Group became the largest automaker of Iran with around 50 percent of the auto production of the country and Peykan-Shahr became one of the most important edge towns of Tehran (Iran Khodro Website; Informants 7, 9, 12). Iran Khodro was initially capable of producing 3,000 cars annually. In 1978, it reached 100,000 and in 2010, it peaked at 775,555 cars (Iran Khodro Website). Recently, Iran Khodro has established seven additional sites in Iran and six sites in other countries including in Belarus, Azerbaijan, Venezuela, Senegal, Egypt and Syria.

Before 1979, Iran Khodro was 51 percent privately owned (by Ahmad and Mahmoud Khayami) and 49 percent state owned. After the 1979 Revolution, the firm was listed as a nationalized industry, albeit, again, by 2005 and after a new privatization plan, 49 percent of the firm's stock had been sold to private interests (Khayamy Blog; HamshahriOnline 2009; 2011; Informants 2, 4, 7, 10).

Iran Khodro experienced its most severe period of recession between 1985 and 1987, leading to bankruptcy and a vast reduction of the workforce (Iran Khodro Website; Informants 2, 4, 9, 11). Before the 1979 Revolution, the number of employees in the main site of the firm was around 7,000, reducing to 4,000 in 1987. Currently, after recovery, around 10,000 employees are working in the main site and around 55,000 globally (Iran Khodro Website; Informants 2, 4, 7). Many workers are retained on temporary contracts, leading to increased tension over job security since 1996 (Informants 5, 7, 10).

The firm owned the land and built environment of Peykan-Shahr. The initial purpose of the construction of the neighborhood was to accommodate seasonal (and mainly migrant) workers involved in the construction phase of the firm. Afterwards, it was allocated to the firm's workers, including the night shift and on-call workers. The township can accommodate around 6,000 inhabitants (Informants 1, 2, 4, 6, 10). As long as they were working at the firm, workers were allowed to rent their flats for a rent that hardly exceeded ten percent of their wages including electricity and water.

The 1987 recession and its following workforce adjustment plan left many residential units empty. Considering the ongoing Iran-Iraq war and security issues, a few apartments were refurbished and allocated to white-collar workers and managers. By the end of the war (1988), the dramatic rise in the average housing rents in Tehran increased demand in Peykan-Shahr. Thus, favorable apartments were allocated to better-off employees and the rest to workers (Informants 2, 4, 5, 6, 7, 9).

The township contains 50 residential four-storey apartment blocks. Half of them contain eight units and the rest have six in each storey. Small flats are 35 and 40 square meters and large ones are 50 and 60 square meters. All large flats are duplexes ( 25 or 30 square meters in each floor). The allocation of the flats was based on the number of family members, job positions and work experience (Informants 2, 3, 4, 5).

An LPG piped gas system was installed around 2002 before the first phase of sell-offs. But telephone lines were installed later. After the Revolution of 1979 and nationalization of the firm, tenants were allowed to apply for minor internal repairs (Informants 1, 3, 4, 5).

Iran Khodro provided free transportation between the main site and Peykan-Shahr four times a day, for day and night shifts. In addition, there were a few buses assigned to transfer tenants of the township to Tehran (Informants 1, 4, 5, 6). There are public schools in Peykan-Shahr but only at the primary level. Free transportation was provided to secondary level public schools in the neighboring Ekbatan Township. Additionally, the firm provided a cheap kindergarten for tenants (Informants 1, 5, 6).

The firm was responsible for all installation services and major repairs. In addition, a daytime volunteer-run healthcare clinic, financed by the firm, provided general and emergency services, including vaccinations. The firm also allowed Iran Khodro Employees' Consumption Cooperation (all employees of the firm were the shareholders) to establish a co-op supermarket that covered basic consumption needs of the tenants relatively cheaply. Some goods and luxury items were also available with special discounts. There have also been a few shops that had been rented out to non-inhabitant shopkeepers (Informants 1, 2, 5, 6). ${ }^{5}$

\footnotetext{
${ }^{5}$ These salient features separated Peykan-Shahr from its neighboring townships. Shahrak-e-Shahrdari (owned by Tehran Municipality) is an interesting example (see Figure 2). Despite obvious socio-economic differences between the Municipality's employees and Iran Khodro's workers and favorable flats of that township, lack of amenities such as a
} 
Before the sell-offs, the firm assigned a Mayor to manage internal issues including maintenance and improvement of green space, security and guards, to intervene in tensions between tenants, etc. Nevertheless, building maintenance was largely neglected after the 1979 Revolution and war (Informants 1, 5, 6, 7).

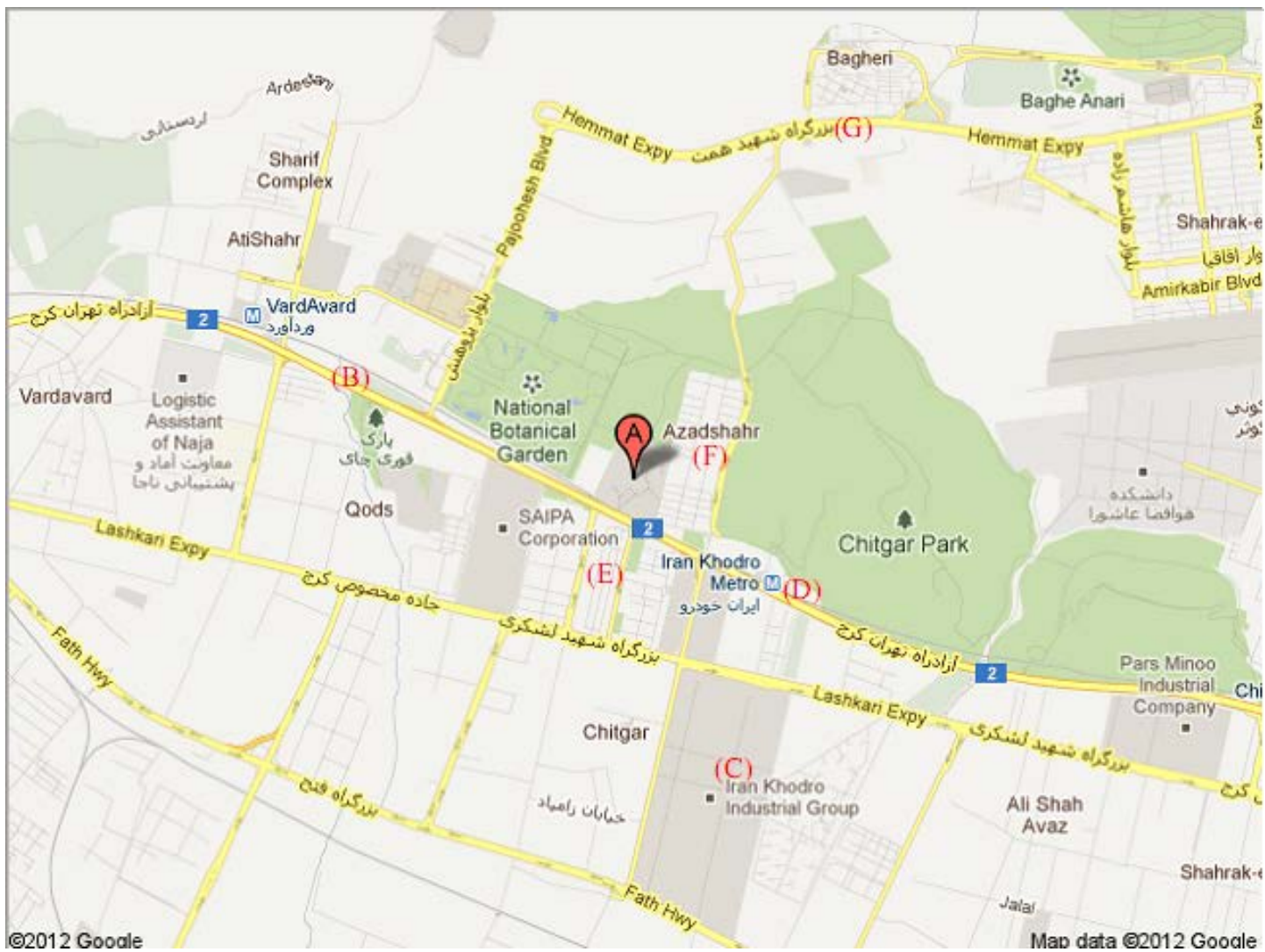

Figure 2: Overview II. (A) Peykan-Shahr (B) Tehran-Karaj Freeway (C) Iran Khodro’s Main Site (D) Iran Khodro Metro Station (E) Shahrak-e-Shahrdari (F) Azad-Shahr (G) Hemmat Expressway. Source: Google Earth.

Long working hours, including long overtime, up to 18 hours a day and holidays shifts, caused great tensions between tenants and within their families. One could encounter these long working-days particularly during the boom periods (during the 70s and after 1996). The first boom consisted of the expansion of production and more efficiencies. During the second period, the firm expanded its production lines again (including assembly line contracts with Mercedes Benz, Peugeot, Renault, etc.). During both periods, there was a considerable increase in the rate of domestic violence, addiction, prostitution and so-on in PeykanShahr (Informants 2, 5, 7, 10,13).

Furthermore, rising living expenses and inadequate income forced women and children to work in an expanding local black market. These parallel jobs consisted of domestic services for the better-off families, but also peddling, drug trading and prostitution. The heterogeneous composition of the tenants caused clear tensions between the few better-off households and the workers' families (Informants 1, 4, 5, 6, 7, 9, 10).

Between 2002 and 2004, the firm decided to sell the residential units and later the township itself. The units have been sold with priority given to occupying tenants. They could buy their flats at 60 percent of the market price, from around 80 million [about US\$12,665] to 110 million IRR [about US\$ 17,415] for 35 to 60 square meter flats). The firm provided a 70 million IRR [about US\$11,082] loan, although purchasers had to clear their loans upon retirement. Many of them could only receive about 20 million IRR [about US\$ 3,166] of the amount of the loan before retirement (Informants 1, 2, 3, 5, 6). Flats that were not bought by the tenants were sold to local shopkeepers, local garage keepers, local plumbers, relatives of the tenants, etc. at their

healthcare clinic, school and coop supermarket forced its inhabitants to come to Peykan-Shahr in order to meet their needs (Informants 1, 2, 3, 5, 6, 8). 
market prices. Many of these new owners have rented out these flats rather than residing in them (Informants 1, 2, 3, 6; Estate Agents).

After sell-offs particular changes occurred in the township. The kindergarten was closed down. The healthcare clinic was sold to the firm's Healthcare Center, which is private and based on contracts with private healthcare companies. The co-op supermarket restricted its services as it could only provide for its members (the firm's remaining workers). This allowed local shopkeepers (most of whom had bought their shops) to dominate the local market. The clinic and supermarket no longer offered free services or discounts on goods.

Private companies and the Municipality undertook the management of sewage, green space and lighting (Informants 1, 2, 4, 5; Tehran Municipality). All the duties of the Mayor were assigned to a council consisting of 50 representatives (each apartment block having one representative). However, since the election of these representatives was not democratic (the council sets ideological preconditions for candidates), there have been tensions between inhabitants and the council (Informants 1, 3, 4, 5, 10).

Tensions increased as the firm gave up maintenance and installation services, leaving rotten sewer pipes, boiler rooms and central heating systems (Informants 1, 2, 3, 4). But there has been a big change in the township in last five years, initiated and/or brought about by the inhabitants themselves. Better-off households renovated their flats, intensifying the difference between the best and worst properties. Poorly monitored changes (such as merging two flats or demolishing the pillars) caused serious structural problems, including the recent collapse of two entire apartment blocks (Informants 1, 2, 3, 4).

Furthermore, the sell-offs led to dramatic increases in price. For instance, a 40 square meters flat that in 2004 sold for around 80 million IRR [about US\$12,665], could be sold for 210 million IRR [around US\$ 33,247] in 2006, 800 million IRR [about US\$ 126,654] in 2009, and for 1000million IRR [around US\$ 158,318] in 2011 (Estate Agents). The average annual price rise is 164 percent. This is extremely high given the average annual rate of inflation is 16.7 percent (Central Bank of Iran).

\section{Relative space}

Three spatial changes around Peykan-Shahr should be taken into account. First, by 2005, Iran Khodro metro station on the Tehran-Karaj metro line was established (see Figures 2, 3). The original line had been established five years before in 1999 (Tehran Metro Website). Second, in 2006, Hemmat Expressway connecting Tehran east to west was extended to Peykan-Shahr (Figure 2). Assuming no major traffic jams, it only takes 15 minutes by car from the township to the city center (the Tehran Municipality). Third, a slum surrounding the township called Azad-Shahr (see Figures 2,4) was successfully redeveloped. The redevelopment (and gentrification) of Azad-Shahr started in 2010, resulted in a dramatic price hike in land and housing. It is hard to find a flat smaller than 60 square meters there. By the end of 2011, a 60 square meter flat in this development could be sold at least for 1,800 million IRR [about US\$ 284,970] (Estate Agents; Informants 1, 3, 4).
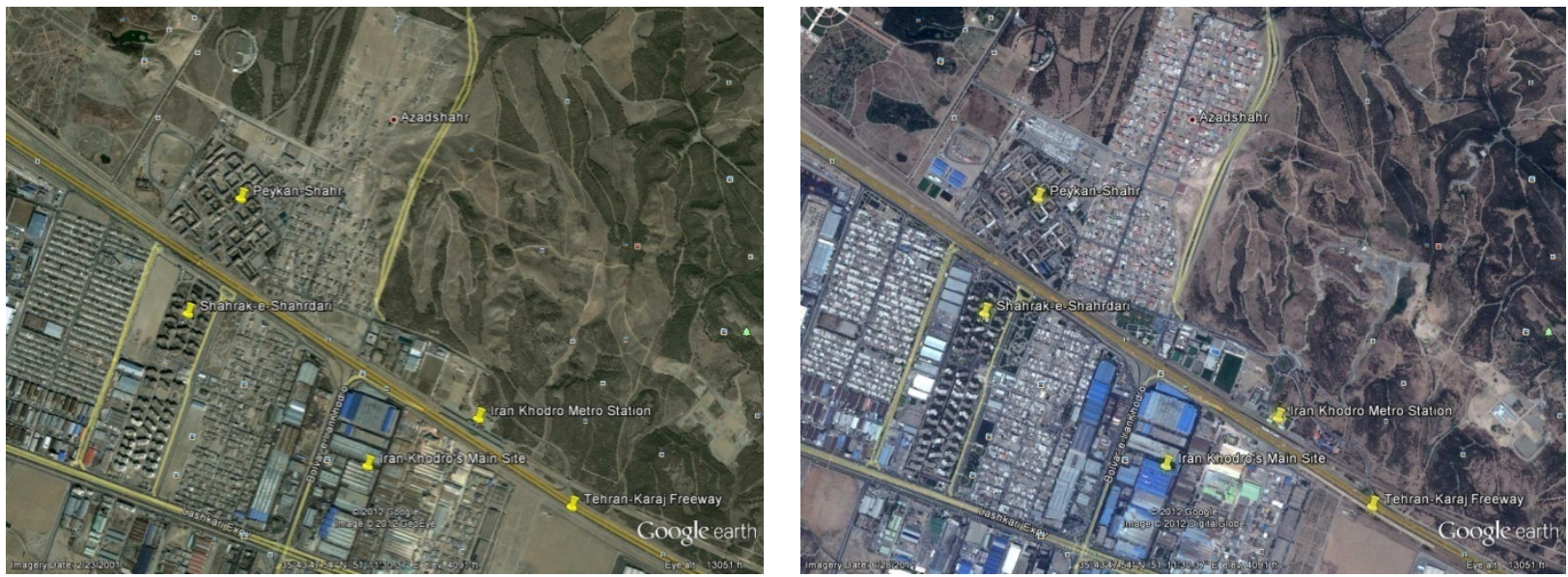

Figure 3: Development of the region, comparing 2001 and 2011. Source: Google Earth. 


\section{Ecology}

The first and the most cited complaint of the inhabitants since the construction of the metro line is noise. The second issue is air pollution caused by aerosols and particles produced by the new phase of construction in Azad-Shahr. Because these air quality issues were new, they are of particular importance for the inhabitants of Peykan-Shahr (Informant 1, 2, 3, 4, 6).

Other ecological problems linked to the urbanization of Tehran and construction of Peykan-Shahr should be highlighted. Firstly, poor technology and installation caused nitrogen and sulfur imbalances in the sewers. The sewers lead to the southern parts of the city and, along with agricultural irrigation, cause extremely significant pollution (HamshahriOnline 2010; Ettelaat). Secondly, Tehran had fertile soil at the beginning of the urbanization process but it is now exhausted and degraded across wide areas. Thirdly, a metabolic rift occurred due to the dislocation of the rural population and their separation from nature at the beginning and during the construction phase of the firm, in order to work as migrant-seasonal workers, and then, as resident industrial labor.
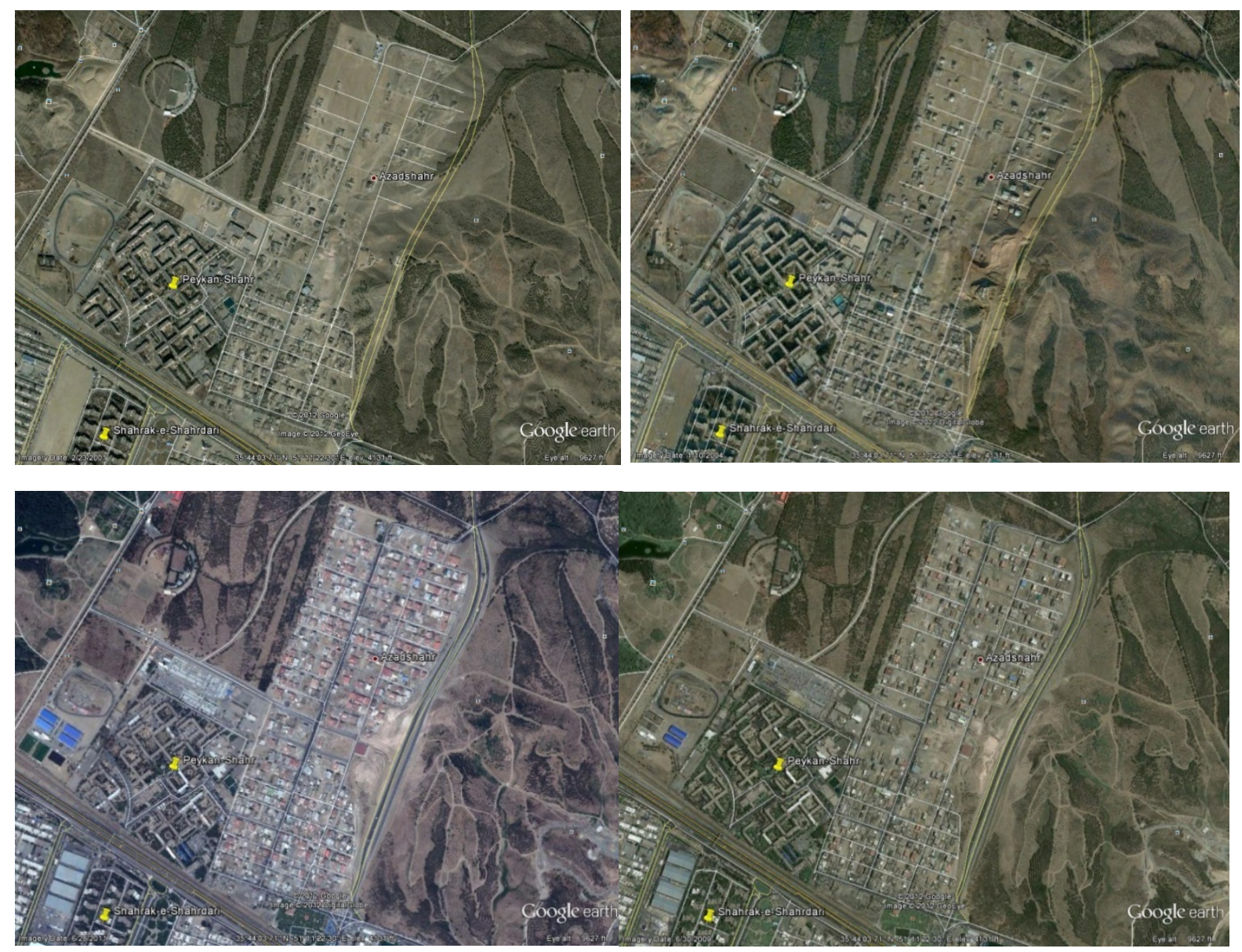

Figure 4: The process of redevelopment of Azad-Shahr (from top left clockwise) 2001, 2004, 2009, 2011. Source: Google Earth.

\section{Analysis}

The Iranian economy and the construction sector

This history of changing land and property values and ownership needs to be set in context. The estimated values for Iran's GDP in purchasing power parity (PPP) exchange rates for 2011 was US\$ 990,800 million, making it the $18^{\text {th }}$ largest economy in the world, while its GDP per capita (PPP), again for 2011, was US\$ 13,200-93 ${ }^{\text {th }}$ of 226 countries (CIA the World Factbook). Its Gini coefficient was 0.44 in 2006 (which ranked it the $92^{\text {nd }}$ most unequal of 140 nations). The HDI index in 2011 was 0.707 (89 ${ }^{\text {th }}$ of 187) (Ibid.; 
UNDP). Despite a healthy GDP, capitalism in Iran has always been struggling against crucial constraints; economies of scale, a lack of integration into the global market, and a low rate of productivity. Capital cannot concentrate (i.e., concentrate in large firms) sufficiently to secure economic development. The major share of the industrial sector is made up of "small manufacturing enterprises" (Nomani and Behdad 2006: 44; Raisdana 2001). The problem of capital concentration intensified after the failure of structural adjustment programs in the mid 1990s following massive social protests (Nomani and Behdad 2006).

The modernization of agriculture (starting with land reforms in the early 1960s), together with urbanization and massive investments in construction and infrastructure, has led to a boom in urban housing construction (Hessamian et al. 2008). This is one of the main reasons for the massive immigration of (mostly unskilled) rural laborers to the cities (Raisdana 2001). Today construction accounts for more than 60 percent of total capital formation (Raisdana 2001; 2002). The boom has allowed housing prices and rents to rise dramatically. Housing expenses make up to 70 percent of low-income renter households' monthly income (Ibid.). A higher rate of profit in the construction sector allows capital to centralize to some degree. Small enterprises and individual developers still form the majority of investors (Raisdana 2001) but a few construction companies have grown and even obtained international partners. Kayson's projects in Venezuela and Sudan are examples (see www.kayson-ir.com).

\section{Raisdana and gentrification theory}

As already mentioned above, Raisdana's analysis of the political economy of housing (2001) was the starting point for my analysis. He believes a skewed distribution of income is responsible for the price hike in housing. According to him, higher-income groups have the opportunity to appropriate the favorable sites in inner and northern Tehran. These plots are more valuable because of their proximity to the city center as well as better communication times and transportation. Therefore, higher-income groups can manipulate prices by monopolizing land and making improvements, and then apply monopoly pricing. They can also manipulate the supply/demand nexus by leaving their buildings vacant until market prices rise.

Raisdana's position applies the concept of differential rent to explain rents yielded from different plots. As for gentrification, which he disputes, he argues that low income neighborhoods are not favorable for higher-income groups (or 'gentry'); secondly, even if they move into those redeveloped areas, their occupancy period is usually less than 3 years; thirdly, finance capital is not involved in the process; fourthly, the period of physical turnover of the built environment is shorter than in the cities of advanced capitalist countries; and lastly (extrapolating to my study) a location like Peykan-Shahr is not located in the inner city. From these points, he concludes that gentrification theory, in its classic definition, cannot be meaningfully related to Peykan-Shahr and places like it (Ibid.). I argue against Raisdana, that gentrification theory contains very relevant concepts to our case, and with due modification could, and indeed should, be applied to PeykanShahr if one is to gain a deeper insight into the roots of its working class inhabitants' displacement and social and ecological problems.

\section{Elaborating gentrification theory in Peykan-Shahr}

By definition, gentrification theory has two interconnected sociological and economic aspects. Raisdana is quite right that the dislocation of workers in Peykan-Shahr has not led to a replacement of the workers by the middle class (or gentry). Nonetheless, I argue that a replacement of petty bourgeoisie e.g. shopkeepers, garage keepers, etc. could still indicate to some extent a sociological change in ownership and occupancy. Even if events at Peykan-Shahr cannot be directly accounted for by classic gentrification theory, the conceptual frame of the theory is quite valuable in shedding light on our case.

There have been particular geographical (spatial) and economic factors involved in the process of making rent gaps, the main driving forces of gentrification process (see; Harvey 1985: 102; Clark and Gullberg 1997: 257; Murray 1978: 26). These factors are;

a) investment in infrastructure (the Iran Khodro metro station and Hemmat expressway);

b) redevelopment (and gentrification) of the neighboring area of Azad-Shahr;

c) disinvestment in, and abandonment of, the built environment.

These factors have played a clear role in widening the rent gap. Together with proliferation of real estate agents in the region and considerable rise in apartment prices, which emerged as a result of the widened rent gap, gentrification was eventually stimulated in the neighborhood.

Furthermore, the price hike after sell-offs indicates an existence of a value gap, at least to some extent. However, it should be emphasized that, in a concrete sense, private ownership of the township by the firm could by no means be compared to public rental housing. Rent gap combined with the value gap seems more capable of explaining the gentrification process in Peykan-Shahr (see Clark 1992). 
As we have seen above, for many gentrification theorists, the dynamics of gentrification in the global South is related to the dynamics of finance capital in a neoliberal context. Here, a brief discussion on the state of finance capital in Iranian economy is needed. First, let me start with a brief review of the Marxian understanding of the concept. Marx in Capital made a clear distinction between merchant's capital (based on the role of money as money) and interest-bearing capital or IBC ("based on the role of money as capital") (Fine and Saad-Filho 2004: 142). The latter "is not the act of borrowing from a bank or the payment of interest . . . but the use to which the loan is put"; it must be only used in a form of industrial capital (Ibid.). He also distinguished IBC from money-dealing capital (MDC) or fictitious capital, which deals with maximization of profit out of speculation, and a generalized credit system (Ibid.; see also Harvey 2006). Conceptualization of finance capital, however, is made years later by Hilferding (1910) to explain a new stage in the capitalist mode of production in which financial capital owned by banks has been integrated with industrial capital (with or without state intervention). Preconditions for this are an existence of a free market economy and independence of the central bank.

But what distinguished finance capital in the early $20^{\text {th }}$ century from finance capital of the last 30 years? First and foremost, in the last 30 years, finance as "the creation of debts (loans) as a means of profitmaking has been spectacularly lucrative" (McNally 2011: 86). Profitability of the financial sector thus, above all, helped the whole economy to recover, at least to some extent, from the previous cycle of the falling rate of profit, especially in the industrial sector. The process was eased by "the maintenance of low interest rates by the Federal Reserve" in the case of the USA (Mattick 2011: 64). It also allowed a massive move towards speculation. "Avenues for speculation were multiplied by the invention of new 'financial instruments', such as derivatives, swaps and the now famous 'securitization' of various forms of debt, including home mortgages" (Mattick2011: 61).

The Iranian financial sector is different. Firstly, the Central Bank of Iran is not independent: it remains dependent to the Ministry of Economic Affairs and Finance. Secondly, the Central Bank regulates activities of the financial sector including interest rates (min. 14 and max. 35 percent), and loan amounts (Central Bank of Iran). Furthermore, in the case of housing, only one state-owned bank (Bank Maskan [meaning 'housing bank']) is allowed to lend money to its customers (Ibid.). Its loan amount cannot be more than 10 percent of the price of a normal flat in Tehran, with a 14 percent interest rate and strong guarantees. Thirdly, the new financial instruments (including mortgages), discussed above, as well as financial institutions such as hedge funds, venture capital, private equity funds, clearing banks and the like are still embryonic. Fourthly, the output of the financial sector (Table 1), despite tripling in the last 20 years, is still recognizably low.

\begin{tabular}{|cccccccc|}
\multicolumn{7}{c|}{$\begin{array}{c}\text { Financial Sector Output: } \\
\text { \% of GDP }\end{array}$} \\
\hline 1991 & 1996 & 2001 & 2006 & 2007 & 2008 & 2009 & 2010 \\
\hline 1.05 & 1.02 & 1.97 & 2.78 & 2.79 & 3.09 & 3.36 & 3.02 \\
\hline
\end{tabular}

Table 1: Financial Sector Output: \% of GDP. Source: Statistical Center of Iran, Year Book.

Now, considering a lack of finance (or, banking) capital integrated with and controlling the construction sector, we must ask what makes investment in this sector so profitable, and why capital prefers to concentrate on construction rather than in the industrial sector? To this end, it is useful to rethink rent theory. Harvey (2006) (and also Smith [1996] and Clark [2004]) focuses on Marx's two concepts of differential rent and their systematic interplay to explain urban spatial change. The conceptual framework of differential rent might be quite pertinent to analyzing single cases/sites (e.g. in case of Azad-Shahr as intensive capital investment in a marginal plot) and especially in favorable inner city locations in Tehran. But it does not help in explaining the long-term tendency of capital flow from industry into construction.

Some peculiarities of Iranian political economy need to be considered here. The Iranian economy has been struggling with several politico-economic challenges since the 1979 Revolution. US-led sanctions together with internal political tension have restricted the opportunity to integrate into the global market especially after the failure in implementation of a neoliberal agenda in the 90s (Raisdana 2001; 2002; Nomani and Behdad 2006). Thus, as discussed above, insufficient concentration of capital, low import of technology, low investment in fixed capital (esp. in the industrial sector), and in short, low productivity of capital, are all consequences of the (semi-) isolation of Iranian economy from the global markets.

These barriers could help us explain capital's tendency to flow from the industrial sector to construction since there is less impediment to investment. The construction sector is less dependent on technology than the industrial sector. Instead of constant capital (e.g. high levels of imported technology), capital could rely on variable capital (living labor for construction work, and more basic technology). The existing politico-economic situation in Iran facilitates this. Around 70 percent of construction laborers are immigrant/unskilled workers with a very low level of income and job security (Raisdana 2001). A reserve 
army of unemployed labor lacking free and independent trades unions allows capital to lower real wages with no chance of bargaining (Hessamian et al. 2008; Nomani and Behdad 2006; Nomani and Behdad 2011). Therefore, the organic composition of capital (i.e. the ratio of constant capital to variable capital) in the construction sector is lower and the rate of exploitation (i.e. the ratio of surplus value to variable capital) is higher than the social average.

Now, assume the average rate of profit in the industrial sector to be at 3 percent. The average rate of profit in the construction sector, due to lower costs of both constant and variable capital, can be 8 percent. The return of capital (over 40 percent), therefore, is the sum of profit and rent. This rent is responsible for abovenormal profitability of housing in Iran secured by the lower organic composition of capital and higher rate of exploitation in this sector than the social average, which lets the prices of the products of this sector reflect "their value rather than post-equalization process of production" (Murray 1977: 107). The rent that is yielded here at the expense of labor and (as we will see in the next section) nature's deterioration, accordingly, is absolute rent.

In summary, the patterns of spatial change in Peykan-Shahr can be explained by gentrification theory. A compromise regarding the sociological aspect of the theory is to consider the class displacement in social terms (the role in social production) rather than economic (the level of income). As for the economic aspect of gentrification theory, I relate the theory to a case like Peykan-Shahr by identifying changes in relative space as the main stimuli in widening a rent gap and changes in tenure in widening a value gap; while also redirecting rent gap theory based on the concept of absolute rent.

\section{Elaborating the theory of metabolic rift in Peykan-Shahr}

The process of redevelopment of Peykan-Shahr has had considerable socio-ecological impacts. I have categorized these in two categories: those that emerged as a consequence of development of the neighborhood and those that specifically occur after sell-offs. The first category consists of soil degradation as the result of the construction of the township, the dislocation of rural population and later nitrate and sulfate imbalances caused by a poor urban sewage system. All in all, these reflect expected socio-ecological impacts of urbanization of the region. The second category consists of air pollution following the new phase of construction, intensified soil degradation in the process of redevelopment, and dislocation of workers from their houses. Social ecology and the theory of metabolic rift provide a theoretical basis to analyze the socioecological impacts of redevelopment of Peykan-Shahr in two ways. First, they relate ecological unsustainabilities to historically specific social relations and capitalism's inherent "contradiction between usevalue and exchange-value" (Burkett 1999: 22) and second, they contextualize the changes in human labor in terms of ecological unsustainability.

Traditionally, the theory of metabolic rift focuses on the process of urbanization and the transformation of land use and the economy from rural to urban. To extend this to my case, let me first probe Iran Khodro's reasons for establishing the housing development. In general, suburbanization of workers could be seen as accompanying industrial location trends (Smith 1996). Proximity of the workforce reduces travel time, and extraction of surplus value is eased. ${ }^{6}$ In particular, there were very limited basic amenities at the time of the establishment of Peykan-Shahr. The main economic stimuli were the very low land rent at the time, and the opportunity for free appropriation of land (thanks to land reforms). The initial rift, therefore, occurred as a dislocation of the rural population in the township and their replacement with an industrial workforce, in addition to depletion of natural resources on the site.

Apart from the metabolic rift occurring during the construction phase, pressured working conditions including extended working days (up to 18 hours), to extract absolute surplus value which physically deteriorated workers and their future generations (as natural beings). This caused a socio-ecological metabolic rift in terms of labor reproduction. To quote Marx;

\footnotetext{
${ }^{6}$ It is interesting to note that a similar process and social relation were noticed by Engels as early as 1845 . He states, "Population becomes centralised just as capital does; and, very naturally, since the human being, the worker, is regarded in manufacture simply as a piece of capital for the use of which the manufacturer pays interest under the name of wages. A manufacturing establishment requires many workers employed together in a single building, living near each other and forming a village of themselves in the case of a good-sized factory. They have needs for satisfying which other people are necessary; handicraftsmen, shoemakers, tailors, bakers, carpenters, stonemasons, settle at hand. The inhabitants of the village, especially the younger generation, accustom themselves to factory work, grow skillful in it, and when the first mill can no longer employ them all, wages fall, and the immigration of fresh manufacturers is the consequence. So the village grows into a small town, and the small town into a larger one. The greater the town, the greater its advantages. It offers roads, railroads, canals; the choice of skilled labour increases constantly, new establishments can be built more cheaply because of the competition among builders and machinists who are at hand, than in remote country districts, whither timber, machinery, builders, and operatives must be brought; it offers a market to which buyers crowd, and direct communication with the markets supplying raw material or demanding finished goods. Hence the marvelously rapid growth of the great manufacturing towns" (Engels 1973: 60-61; quoted in Burkett 1999: 122-123).
} 
When the working day is prolonged, the price of labour-power may fall below its value, although that price nominally remains unchanged, or even rises. The value of a day's labourpower is estimated... on the basis of its normal average duration, or the normal duration of the life of a worker, and on the basis of the appropriate normal standard of conversion of living substances into motion as it applies to the nature of man. Up to a certain point, the increased deterioration of labour-power inseparable from a lengthening of the working day may be compensated for by making amends in the form of higher wages. But beyond this point deterioration increases in geometrical progression, and all the requirements for the normal reproduction and functioning of labour-power cease to be fulfilled. The price of labour-power and the degree of its exploitation cease to be commensurable quantities (Marx 1990, I: 664; quoted in Burkett and Foster 2006: 122).

Nevertheless, the rift is not limited to the process of automobile production. Other aspects included the existence of a local black market, and a lack of free time for activities outside of work. This led to family tensions. I would argue that the dislocation of workers from their houses, particularly due to the vital role of housing in the Iranian economy and because it has survival use-value for workers, would again cause an energetic metabolic rift in terms of labor reproduction and the deterioration of working power.

Since many workers in Peykan-Shahr could not buy their flats, they had to rent them from the new owners under new market conditions (costing up to 150 percent of their wages), or move. For the few white collar inhabitants there were more expensive rental apartments in neighboring areas. For others, some moved to other cities such as Karaj, Malard, Shahriar, and Shahr-e-Qods. Some had to acquire a second (or even third) job to be able to cover their households' new living expenses. These forms of dislocation have severe impacts on travel time and squeeze free time, ironically reducing their productivity in the longer term. Furthermore, the length of physical turnover of the built environment in Tehran is around 20-30 years (Raisdana 2001; 2002). That means most buildings face being demolished for redevelopment in that timeframe, as the invested capital is already valorized (Smith 1996). This process generates a considerable amount of construction trash going to landfills, and adds inorganic materials. Following the metabolic rift concept, turnover of building stock means soil cannot recover its "constituent elements" (Foster 1999).

Absolute rent plays a key role here. In order to extract rent without compromising desirable investment return, capital is forced to intensify its pressure on labor and on nature. Where there is housing redevelopment, gentrification mediates capital's pressure on labor/nature by intensifying a metabolic rift in labor reproduction and natural resource degradation. Furthermore, the social tension over land rent between landowner/capitalist/laborer, in an abstract sense, reflects the tension between use-value and exchange-value as it indicates appropriation and commodification of a natural condition of production or reproduction (land or housing) by one class at the expense of another. Therefore, considering the crucial position of housing in Iranians' socio-economic life, I argue that tension over rent between the landlord and capitalist in the process of redevelopment and gentrification will intensify the exploitation of labor/nature and also cause a metabolic rift by dislocating workers from their housing.

\section{Conclusion}

The study of the socio-ecological impacts of spatial change in Peykan-Shahr illustrates the necessity of a concrete analysis of the peculiarities of Iranian capitalism. It shows how politico-economic constraints on capital accumulation determine processes of spatial change and lead to marked socio-ecological consequences. By offering an analysis based on political economy, the study shows that the dislocation of workers (following housing sell-offs in this case) has considerable impacts in terms of socio-economic and socio-ecological change, but with less change to the built environment for the present.

Returning to the structural mechanisms underlying the process of gentrification that lie in capitalism's inherent class conflict over appropriation of the means of production (land, and, in this case, housing) I critique Raisdana's approach to the housing question in Iran. Raisdana's analysis is historically contingent, as he focuses on policy-making rather than the structural specificity of Iranian capitalism.

The critique of socio-ecological metabolic rift caused by capitalism's inherent tendency towards accumulation of capital contributes to a Marxist understanding of sustainability (Foster 2000). What I have tried to demonstrate is that gentrification, by mediating and intensifying capital's exploitation of labor/nature (by dislocating workers-as natural beings-from their means of subsistence), caused a socio-ecological metabolic rift. An appropriate action leading towards sustainability, in this particular case, needs to address the metabolic rift and the class relations behind it. This has implications for our understanding of the increasingly popularized and co-opted concept of sustainability.

Iranian capitalism has a suppressive power over workers, not only within the process of production but also in social life. Housing plays a vital role in workers' lives and there are class tensions over appropriation 
of land and rent (i.e. tension between landed property/capital/labor). Therefore, understanding the underlying class mechanisms that rule the process of gentrification, and tensions over appropriation of space is important for worker empowerment.

A coherent understanding of socio-ecological consequences of gentrification and resulting dislocation of workers from their houses necessitates a synthesis of social ecology and the political economy of space. Neither of these two theoretical strands explained the underlying process and stimuli of urban change in isolation, or its socio-ecological impacts. Applying Lakatos's methodology (1999: 130), I have tried to address these two strands in a methodologically 'progressive' way. Gentrification theory explains spatial change in the township, while the theory of metabolic rift explains socio-ecological impacts of that spatial change.

Explaining the case of Peykan-Shahr in this way is not theoretically straightforward, and requires modification of both theoretical strands. Gentrification theory, at least in its classic characterization, is largely related to advanced capitalist metropolises and its global spread is seen as a result of the spread of neoliberal governance. The presence of gentrification in Iran was strongly refuted by Iranian economists like Raisdana (2001). But gentrification theory remains relevant to the case if its economic components such as the rent/value gap and its analysis of relative space are used to analyze spatial changes in terms of social class. The article also tried to open a new discussion on rent theory, and to apply the Marxian concept of absolute rent in the Iranian economy.

Another difficulty in synthesizing the two strands of theory is the relevance of the metabolic rift concept to an urban context where workers become dislocated. Again, by returning to Marx' labor theory of value and the notion of energetic metabolism, I extended the application of the theory of metabolic rift to analyze gentrification and dislocation of workers in Peykan-Shahr with regard to energy dissipation, absolute surplus value and labor reproduction. The spatial changes in the neighborhood have been explained in terms of an energetic metabolic rift in labor reproduction, a deterioration of labor power, and an intensified exhaustion of soil.

\section{References}

Atkinson, R. and G. Bridge. (ed.) 2005. Gentrification in a global context: the new urban colonialism. London: Routledge

Burkett, P. 1999. Marx and nature: a red and green perspective. New York: St. Martin's Press.

Burkett, P, and J. B. Foster. 2006. Metabolism, energy, and entropy in Marx's critique of political economy: beyond the Podolinsky myth. Theory and Society 35(1): 109-156.

Central Bank of Iran.2009. متوسط نرخ تورم سال، نرخ تغييرات سالانه شاخص قيمت در بإيان هر سال و متوسط نرخ تورم درأ [The average rate of annual inflation between 1989 and 2008]. June 08. [accessed January 09, 2013].http://www.cbi.ir/page/6244.aspx

Central Bank of Iran.2013. ابز ارهاى سياست يُولى در ايران [Fiscal Policies instrument in Iran]. [accessed August 4, 2013]. http://cbi.ir/page/1512.aspx

Central Bank of Iran. 2013. بانك هاو موسسات مالى مجاز [Registered and licensed banks and financial institutes]. [accessed August 4, 2013]. http://cbi.ir/simplelist/1541.aspx

CIA (Central Intelligence Agency), The World Factbook. 2006. Country comparison: distribution of family income-Gini Index. [accessed January 09, 2013]. https://www.cia.gov/library/publications/the-worldfactbook/rankorder/2172rank.html

CIA (Central Intelligence Agency), The World Factbook. 2011 est. GDP (Purchasing Power Parity). [accessed January 09, 2013]. https://www.cia.gov/library/publications/the-worldfactbook/rankorder/2001rank.html

CIA (Central Intelligence Agency), The World Factbook. 2011 est. GDP Per Capita (PPP). [accessed January 09, 2013]. https://www.cia.gov/library/publications/the-world-factbook/rankorder/2004rank.html

Clark, E. 1992. On gaps in gentrification theory. Housing Studies 7 (1): 16-26.

Clark, E. 1995. The rent gap re-examined. Urban Studies 32 (9): 1489-1503.

Clark, E. 2004. Rent rhythm in the flamenco of urban change. In Mels, T. (ed.) Reanimating places: a geography of rhythms. Aldershot: Ashgate. Pp 147-160.

Clark, E. 2010. The order and simplicity of gentrification-a political challenge. In L. Lees, T. Slater and E. Wyly (eds.). The gentrification reader. London and New York: Routledge. 24-29

Clark, E, and A.Gullberg. 1997. Power struggles in the making and taking of rent gaps: the transformation of Stockholm City. In O. Källtorp, I. Elander, O. Ericsson, and M. Franze (ed.). Cities in transformation transformation in cities: social and symbolic change of urban space. London: Ashgate. Pp. 248-265.

Creswell, J.W. 2007. Qualitative inquiry and research design: choosing among five traditions. London: Sage. Davis, M. 2006. Planet of slums. London: Verso. 
Engels, F. 1973 (1845). The condition of the working class in England. Moscow: Progress Publishers.

Ettelaat. آب جنوب تهران به نيترات آلوده است [Pollution of water with nitrate in southern Tehran]. [accessed March 10, 2012]. http://www.ettelaat.net/08-oktober/news.asp?id=32796

Fine, B. and Saad-Filho, A. 2004. Marx's Capital. (4. ed.) London: Pluto.

Foster, J.B. 1999. Marx's theory of metabolic rift: classical foundations for environmental sociology. American Journal of Sociology 105 (2): 366-405.

Foster, J. B. 2000. Marx's ecology. New York: Monthly Review Press.

Foster, J. B, B. Clark, and R. York. 2010. The ecological rift: capitalism's war on the Earth. New York: Monthly Review Press.

Glass, R. 1964. London: aspects of change. London: Mac Gibbon and Kee.

HamshahriOnline. 2009. واكذارى ايران خودرو و ساييا به بخش خصوصى [Privatization of Saipa and Iran Khodro]. October 25. [accessed April 08, 2012]. http://www.hamshahrionline.ir/news-93620.aspx

HamshahriOnline. 2010. كزارش وزارت بهداشت در باره آلودكى آب تهران [The Ministry of Health's report on water contamination in Tehran]. June 14. [accessed March 10, 2012]. http://www.hamshahrionline.ir/news109699.aspx

HamshahriOnline. 2011 آشنايى با سياست هاى كلى اصل 44 قانون اساسى [An introduction to general policies of Act 44 of the Constitution]. July 3. [accessed April 08, 2012]. http://www.hamshahrionline.ir/news139341.aspx

Harvey, D. 2006 (1982). The limits to capital (New and fully updated ed.) London: Verso.

Harvey, D. 1985. The urbanization of capital. Oxford: Blackwell.

Hay, I. 2008. Ethical practice in geographical research. In N.J. Clifford and G. Valentine (eds.). Key methods in geography. London: Sage. Pp37-53.

Hedin, K., E. Clark, E. Lundholm, and G.Malmberg. 2012. Neoliberalization of housing in Sweden: gentrification, filtering, and social polarization. Annals of the Association of American Geographers 102 (2): 443-463.

Hessamian, F., G. Etemad, and M. Haeri. 2008. شهرنشينى در ايران [Urbanization in Iran]. Tehran: Agah Publishing House.

Hilferding, R. 1910. Finance capital. A study of the latest phase of capitalist development. Edited by Tom Bottomore. (Routledge \& Kegan Paul, $\quad$ London, 1981 ). At: http://www.marxists.org/archive/hilferding/1910/finkap/

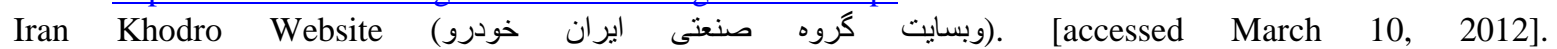
http://www.ikco.com/Fa/Intro.aspx

Khayamy Blog. احمد و محمود خيامى: زندكينامه احمد و محمود خيامى مؤسسين ايران ناسيونال (اير ان خودرو كنونى), [Biography of Ahmad and Mahmud Khayami: Founders of Iran National (Iran Khodro)]. [accessed March 10, 2012]. http://khayamy.blogfa.com

Lakatos, I. 1999. Falsification and the methodology of science research programmes. In Lakatos, I. and A. Musgrave (eds.) Criticism and the growth of knowledge. Cambridge: Cambridge University Press. Pp 91-196.

Lees, L., T. Slater, and E. K. Wyly. 2008. Gentrification. New York: Routledge.

McNally, D. 2011. Global slump: the economics and politics of crisis and resistance. Oakland, CA: PM Press.

Marx, K. 1990 (1867). Capital: a critique of political economy, Vol. 1. London: Penguin Books.

Marx, K. 1991 (1894). Capital: a critique of political economy, Vol. 3. London: Penguin Books.

Mattick, P. 2011. Business as usual: the economic crisis and the failure of capitalism. London: Reaktion.

Murray, R. 1977. Value and theory of rent: part one. Capital \&Class 1 (3): 100-122.

Murray, R. 1978. Value and theory of rent: part two. Capital \&Class 2 (1): 11-33.

Nomani, F, and S. Behdad. 2006. Class and labor in Iran: did the Revolution matter? New York: Syracuse University Press.

Nomani, F, and S. Behdad. 2011. Iranian labor and the struggle for independent unions. Tehran Bureau. April 18. [accessed April 20, 2012].

http://www.inthesetimes.com/working/entry/7225/iranian_labor_and the struggle_for_independent_unions

Raisdana, F. بررسيهاى كاربردى توسعه و اقتصاد ايران. 2001 [Applied development investigation and Iran's economy]. Tehran: Cheshmeh Publications.

Raisdana, F. 2002. اقتصاد سياسى توسعه [Political economy of development]. Tehran: Negah Publisher.

Slater, T. 2006. The eviction of critical perspectives from gentrification research. International Journal of Urban and Regional Research. 30 (4): 737-757. 
Slater, T., W. Curran, and L. Lees. 2004. Gentrification research: new directions and critical scholarship. Environment and Planning A36 (7): 1141-1150.

Smith, N.1996. A new urban frontier; gentrification and the revanchist city. London: Routledge.

Smith, N. 1986. Gentrification, the frontier, and the restructuring of urban space. In Smith, N. and P. Williams (eds.) Gentrification of the city. (2007 [1986]). London: Routledge. Pp 15-34.

Statistical Center of Iran. Iran statistical Year Book. [accessed August 4, 2013].

http://salnameh.sci.org.ir/AllUser/DirectoryTreeENComplete.aspx

Tehran Metro. Tehran Urban and Suburban Railway Operation Co. [accessed April 08, 2012]. http://metro.tehran.ir/Default.aspx?tabid=150

Tehran Municipality, district 22 دلايل نوجيهى احداث و تكميل بزركر اه همت غربى. (شهردارى تهران، منطقه 22) [Reasons for Development of Western Hemmat Expressway]. [accessed April 09, 2012]. http://www.district22.org/assistants/traffic/hemmat_expressway/index.asp

UNDP. 2011. International Human Development Indicators: National Human Development Indicators for Iran (Islamic republic of). [accessed January 09, 2013]. http://hdrstats.undp.org/en/countries/profiles/IRN.html

Williams, C. 2010. Ecology and socialism; solutions to capitalist ecological crisis. Chicago: Haymarket Books.

Yin, R. K. 2009. Case study research; design and methods. London: Sage.

\begin{abstract}
The article aims to understand the forms and processes of socio-ecological changes following sociogeographical dislocation of workers in a working-class neighborhood (Peykan-Shahr) in Iran. The article integrates theories of gentrification and metabolic rift. Existing studies on urbanization in Iran refute the possibility of gentrification. This study, in contrast, by drawing attention to peculiarities of the capitalist economy in Iran, adapts the basic economic mechanisms of gentrification such as the rent/value gap and the concept of absolute rent, concluding that Peykan-Shahr is indeed in a process of gentrification. The theory of metabolic rift adds theoretical dimensions and complexity to the analysis and provides a richer understanding of the case. Grounded in Marx's labor theory of value, the analysis shows that by mediating the exploitation of labor/nature by capital through displacing workers from their houses, gentrification in Peykan-Shahr has caused a socio-ecological metabolic rift in terms of labor reproduction and deterioration of labor power.
\end{abstract}

Key words: Socio-ecological metabolic rift, gentrification, absolute rent, Marxism, labor reproduction, political economy of Iran.

\title{
Résumé
}

Cet article analyse les formes et les processus de changements socio-écologiques qui ont suivi la dislocation socio-géographique des travailleurs dans un quartier (Peykan-Shahr) en dehors de Téhéran, en Iran. L'étude intègre les théories de la gentrification et «rift métabolique». Les études existantes sur l'urbanisation en Iran démentent la possibilité de gentrification. Cette étude, en revanche, attire l'attention sur les particularités de l'économie capitaliste en Iran. Il adapte les mécanismes économiques de base de la gentrification comme l'écart de loyer / valeur et le concept de la rente absolue, concluant que Peykan-Shahr est en effet dans un processus de gentrification. La théorie du rift métabolique ajoute des dimensions théoriques et une complexité à l'analyse et fournit une meilleure compréhension de l'affaire. Fondée sur la théorie du travail de Marx sur la valeur, l'analyse montre que par la médiation de l'exploitation du travail et de la nature par le capital, à travers le déplacement des travailleurs de leurs maisons, la gentrification dans Peykan-Shahr a causé une fracture du métabolisme socio-écologique. Cela s'est produit en termes de reproduction de la main-d'œuvre et la détérioration de la force de travail.

Mots clés: rift socio-écologique métabolique, la gentrification, la rente absolue, le marxisme, la reproduction du travail, de l'économie politique de l'Iran. 


\section{Resumen}

Este estudio se propone entender las formas y los procesos de cambio socio-ecológicos siguiendo la dislocación socio-geográfica de trabajadores en un barrio obrero (Peykan-Shahr) en Irán. El estudio integra teorías de aburguesamiento y de brecha metabólica. Algunos estudios realizados sobre la urbanización en Irán refutan la posibilidad del aburguesamiento. Este estudio, por el contrario, al llamar la atención sobre las peculiaridades de la economía capitalista en Irán, adapta los mecanismos económicos básicos del aburguesamiento, tales como la brecha entre renta y valor y el concepto de renta absoluta, concluyendo que Peykan-Shahr está desde luego en proceso de aburguesamiento. La teoría de la brecha metabólica añade dimensión teórica y complejidad al análisis y le dota de un entendimiento más rico del caso. Basado en la teoría marxista del valor, el análisis muestra que al mediar la explotación de trabajo/naturaleza por el capital mediante el desplazamiento de los trabajadores de sus casas, el aburguesamiento en Peykan-Shahr ha provocado una brecha metabólica socio-ecológica en términos de reproducción del trabajo y deterioro del poder de la mano de obra.

Palabras clave: Brecha metabólica socio-ecológica, aburguesamiento, renta absoluta, marxismo, reproducción laboral, economía política de Irán.

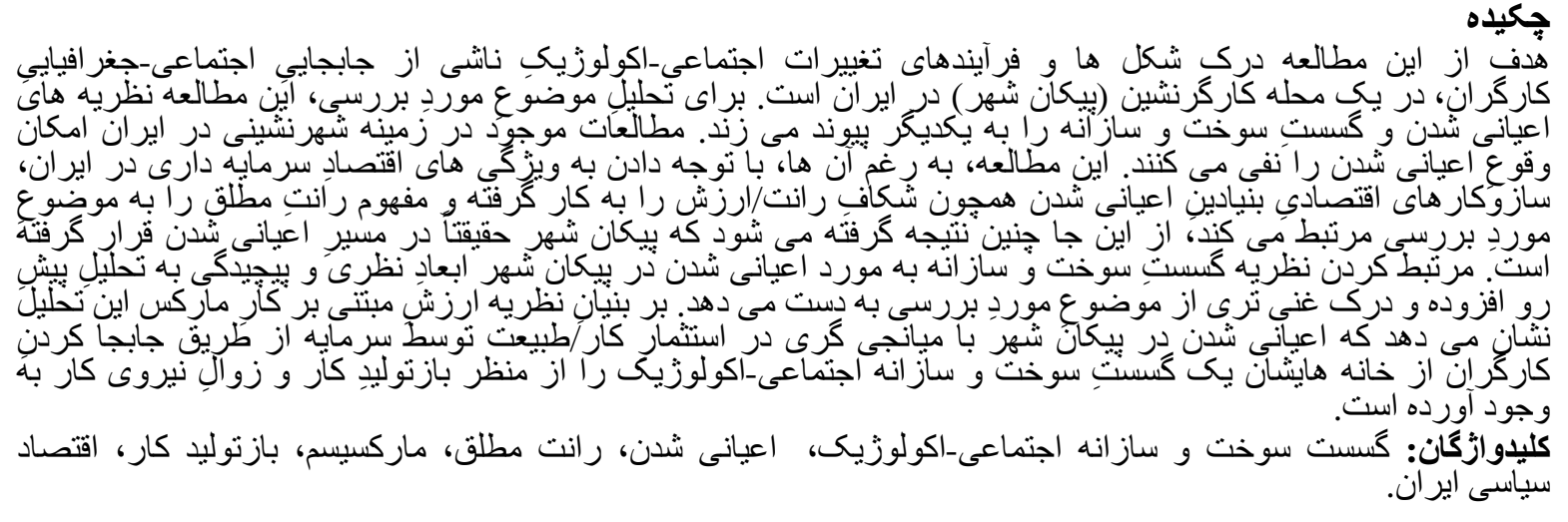

